\title{
SPATIAL DISTRIBUTION AND SYNOPTIC CONDITIONS OF SNOW ACCUMULATION AND SNOW ABLATION IN THE WEST SIBERIAN PLAIN
}

\author{
Ewa BEDNORZ ${ }^{1, *}$, JoANNA Wibig ${ }^{2}$ \\ ${ }^{1}$ Department of Climatology, Adam Mickiewicz University in Poznań, Poland \\ ${ }^{2}$ Department of Meteorology and Climatology, University of Łódź, Poland
}

Manuscript received: December 29, 2014

Revised version: August 15, 2015

\begin{abstract}
BEDNORZ E., WibIG J., 2015. Spatial distribution and synoptic conditions of snow accumulation and snow ablation in the West Siberian Plain. Quaestiones Geographicae 34(3), Bogucki Wydawnictwo Naukowe, Poznań, pp. 5-15, 8 figs, 1 table. DOI 10.1515/quageo-2015-0029, ISSN 0137-477X

ABSTRACT: The mean duration of snow coverage in the West Siberian Plain is approximately eight months in the north to about five months in the south. While the period of intense snow melting is short (one or two months between March and May), snow accumulation persists for most of the cold season. Snow accumulation is associated with negative anomalies of sea level pressure, which means increased cyclonal activity and weaker than normal Siberian High. Much lower anomalies of sea level pressure occur during snow ablation. This suggests smaller influence of air circulation on snow cover reduction in spring.
\end{abstract}

KEYWORDS: snow accumulation, snow ablation, West Siberian Plain, air circulation

*Address of the corresponding author: Ewa Bednorz, Department of Climatology, Institute of Physical Geography and Environmental Planning, Adam Mickiewicz University in Poznań, Poland, e-mail: ewabedno@amu.edu.pl

\section{Introduction}

Snow is a dominant feature of the winter landscape in the moderate zone. Snow cover, which can be observed for a few months each year, has substantial impacts on plants, animals and humans, and it is also an important part of the climate system. Due to its physical features, snow strongly modifies the surface-atmosphere energy budget by increasing surface albedo and isolating atmosphere from the ground (Robock 1980, Robinson and Kukla 1985, Foster 1989). Consequently, snow modifies the boundary layer climate mainly by lowering the surface air temperature (Wagner 1973, Dewey 1977, Walsh et al. 1982). Snow is also a reservoir for fresh water and therefore plays an important role in the hydrological cycle.
The occurrence of snow is an effect of the relationship between air temperature and precipitation, and therefore it is sensitive to climate change (Meehl et al. 2007, Räisänen 2008). Observed and predicted increases in the winter temperature and precipitation in mid- and high-latitudes considerably influence the amount of snow. In mid-latitudes, where winters are mild, temperature increases convert snow to rain, but in high-latitudes, where the climate is cold and winter temperatures remain below zero, despite warming, greater amount of snowfall can be expected (Räisänen 2008). Maximum seasonal snow depth is expected to increase over many northern areas by 2050, with the greatest increase being over Siberia. Despite this, the average snow cover duration is projected to decline by up to 20\% (AMAP 2012). 
The occurrence of snow, as well as other winter weather conditions, such as temperature, cloudiness and precipitation, is largely controlled by atmospheric circulation, particularly in high latitudes where there is no inflow of solar irradiation (Przybylak 2000). Analyses of the Northern Hemisphere snow cover response to macroscale atmospheric circulation were carried out in monthly or weekly time scales and in different spatial scales (global and continental). The North Atlantic Oscillation (NAO) has a great impact on snow cover persistence in Europe and Asia (Gutzler and Rosen 1992, Clark et al. 1999, Bednorz 2004, Falarz 2007, Bednorz and Wibig 2008). Conversely, it has been suggested that the Eurasian snow cover can modify the atmospheric circulation, particularly the intensity of the Arctic Oscillation, thus allowing it to influence climatic conditions in the moderate and polar zones (Cohen and Entekhabi 1999, Saito and Cohen 2003, Allen and Zender 2011, Peings et al. 2013).

Although there are many studies regarding snow cover in Russia and Eurasia and its relationships with atmospheric and oceanic circulation (Tachibana 1995, Ye et al. 1998, Ye 2000, Popova 2001, Ye 2001a, Morinaga et al. 2003, Rikiishi and Sakakibara 2004, Iijima et al. 2007) the previous studies have been based on large time scales datasets (seasonal, monthly or weekly). Many studies have been focused on changes in the length of the snow season (Ye 2001b, Ye and Ellison 2003). The aim of this study is to characterize changes in snow cover depth during the winter season in the West Siberian Plain and to determine synoptic conditions of snow accumulation in winter and snow ablation in spring using daily datasets.

\section{Data and methods}

This study is based on the daily snow depth data collected at 19 stations for 30 winters since $1978 / 1979$ to $2007 / 2008$, obtained from the BMDS (Baseline Meteorological Data in Siberia) version 5.0 dataset (Yabuki et al. 2011). Apart from the snow depth data, values of daily mean air temperature and precipitation totals (coming from the same source) were used for general climatic characteristic. The investigated area covered western part of Siberia, i.e. the lowland called Western Siberian Plain which is spreading between $50^{\circ}$ and $70^{\circ} \mathrm{N}$ and $60^{\circ}$ to $90^{\circ} \mathrm{E}$ (Fig. 1A). The elevation of all stations was lower than 200 $\mathrm{m}$ a.s.l. Snow depth data came from daily measurements taken at three snow measuring rods at 06.00 UTC. The daily mean was calculated by averaging the readings on the three rods, rounded to the nearest whole $\mathrm{cm}$. The days with a snow depth of $\geq 1 \mathrm{~cm}$ were considered as days with snow cover.

To detect daily changes in snow cover depth, the snow depth of a given day was subtracted from the snow depth of the following day. Positive/negative values indicate increases/decreases in snow depth, respectively. Monthly increases/decreases in snow cover depth were calculated by summing the positive/negative values for each month. The main aim of the study concerned the substantial accumulation of snow in winter and intense snowmelt in spring. Therefore, days with an increase in snow cover depth of $\geq 5 \mathrm{~cm}$ in at least two stations in the West Siberian Plain were selected. Congruently, days with a decrease in snow cover depth of $\geq$ $5 \mathrm{~cm}$ in at least two stations were taken to the further analysis.

Relating the the rapid changes in snow depth to synoptic conditions, the 'environment to circulation' approach was applied. Using this method, the circulation classification was carried along a specific environment-based criteria set for a particular environmental phenomenon, i.e., rapid increase/decrease in snow depth in this case (Yarnal 1993, Yarnal et al. 2001, Dayan et al. 2012). Synoptic conditions during the days of abundant snow accumulation or rapid snow melting were considered in terms of pressure patterns, which determine the atmospheric circulation and the transport of air masses. Mean daily sea level pressure (SLP) data were selected from the National Centers for Environmental Prediction (NCEP) - National Center for Atmospheric Research (NCAR) reanalysis data (Kalnay et al. 1996). The resolution of all reanalysis data used in the study was $2.5 \times 2.5 \mathrm{deg}$.

Snowfalls are sometimes influenced by local conditions, therefore only the days with abundant snow accumulation at more than one station were taken into consideration. Composites and anomalies of SLP were computed and mapped for the selected days with snow cover increase and decrease by at least $5 \mathrm{~cm}$ in at least two sta- 

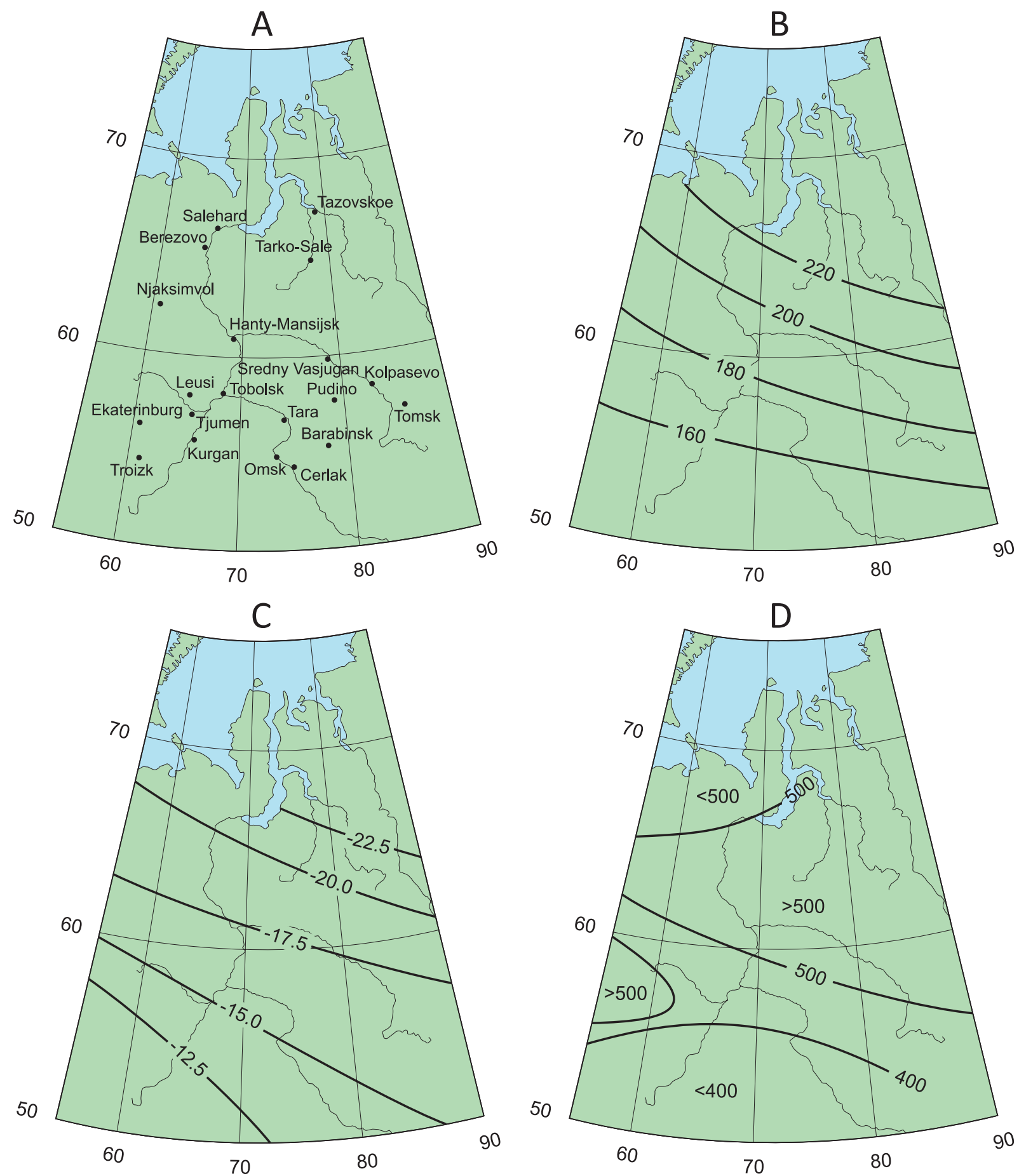

Fig. 1. A - Location of meteorological stations; B - seasonal number of days with snow cover; C - mean air temperature of winter months (December-February) in ${ }^{\circ} \mathrm{C}$; D - annual precipitation totals in mm. Averages for years 1978-2008.

tions. Anomalies for the increases in snow depth were calculated as differences between composite values for the days with intense snowfalls and 30-year seasonal means (October-May). Anomalies for the decreases in snow depth were calculated as differences between composite values for the days with intense snowmelt and 30-year spring means (March-May).
Furthermore, different circulation types were distinguished among the days with heavy snowfalls and among the days with rapid snowmelt. Ward's minimum variance method was used to cluster the standardised daily SLP data (Ward 1963). Both the composite analysis and clustering techniques have been used previously to identify atmospheric circulation patterns asso- 
ciated with heavy snowfalls in the mountains (Birkeland and Mock 1996, Esteban et al. 2005. The Ward's method chosen for clustering in this study is the most frequently used hierarchical clustering technique for climatic classification (Kalkstein et al. 1987).

Additionally, correlation between monthly sums of snow cover increases and indices of macroscale circulation patterns, like Arctic Oscillation (AO) and Siberian High ( $\mathrm{SH}$ ) were computed. Monthly AO indices were derived from Climate Prediction Center databases (Barnston and Livezey 1987). The SH intensity was computed as a normalized regional monthly mean SLP averaged over $70 \mathrm{E}$ to $120 \mathrm{E}, 40 \mathrm{~N}$ to $60 \mathrm{~N}$ for winters 1978/1979-2007/2008 (Gong and Ho 2002), using the NCEP/NCAR reanalysis data.

\section{Results}

The West Siberian Plain is a vast lowland area and is not homogenous in terms of climatic conditions. The mean annual air temperature ranges from over $5.0^{\circ} \mathrm{C}$ in the southwest (Ekaterinburg, Troizk) to below $-5.0^{\circ} \mathrm{C}$ in the north (Tazovskoe, Salehard, Tarko-Sale). The isotherm of the mean annual temperature equal to $0.0^{\circ} \mathrm{C}$ follows the parallel $60 \mathrm{~N}$ and it divides the West Siberian Plain to the colder northern part and the warmer southern part. The air temperature in winter is even more diversified, although, in the entire region winters are very frosty. The mean temperature of the coldest month (January) ranges from about $-25.7^{\circ} \mathrm{C}$ in the north (Tazovskoe) to $-12.4^{\circ} \mathrm{C}$ in the southwest (Ekaterinburg). The very low temperature persists during winter months (December-February) (Fig. 1C), while in autumn and in spring the air temperature changes rapidly. The mean monthly temperature drops below $0^{\circ} \mathrm{C}$ from November to March in the south, and from October to May in the north, which provides the opportunity for snowfall during about half of the year. The mean annual precipitation totals range from 450 to $550 \mathrm{~mm}$ in the central and northern part of the West Siberian Plain and are lower than $400 \mathrm{~mm}$ in the south (Fig. 1D). Precipitation during the cold part of the year, which is necessary for developing the snow cover, is much lower than in the summer, and it ranges from $100 \mathrm{~mm}$ to $150 \mathrm{~mm}$.
The mean duration of snow coverage in the West Siberian Plain is approximately seven-eight months in the north to about five months in the south (Fig. 1B and Fig. 2, upper bar charts). Mean maximum depth of seasonal snow cover reaches values from below $30 \mathrm{~cm}$ in the south (Kugan) to over $80 \mathrm{~cm}$ in the north (Tarko-Sale) and in the east (Tomsk), and it may be observed in February, March or April depending on the region. While the period of snow melting is usually very short (one or two months between March and May), snow accumulation exists for most of the cold season (Fig. 2, lower bar charts). Small reductions of snow depth that are noted during the coldest winter months are caused probably by snow subsidence, and snow drifting. Both processes are intensified by strong wind conditions dominating in winter over the West Siberian Plain.

Further analysis concerned the substantial accumulation of snow in winter and intense snowmelt in spring. Synoptic conditions of snow accumulation and ablation were considered in terms of SLP patterns, which determine the atmospheric circulation and the transport of air masses.

During the long Siberian winter, which lasts from October to May, a vast anticyclone called the Siberian High spreads over Asia with a mean SLP exceeding $1030 \mathrm{hPa}$ in the center, located over the southern border of Russia (Fig. 3). A low pressure zone extends in the northwest from the Icelandic Low towards the northeast, reaching the Barents Sea. Another cyclonal system, namely Aleutian Low, spreads over the north Pacific. Both SLP depressions are divided by the ridge of high pressure that crosses the Arctic Ocean and connects the Siberian High with the North American High.

Maps of circulation patterns responsible for intense snow accumulation (composites and anomalies) show negative anomalies of SLP, which means increased cyclonal activity over the analyzed region. A center of negative anomalies with values exceeding $-7 \mathrm{hPa}$ is located right over the southern part of the West Siberian Plain (Fig. 4). This denotes low pressure systems encompassing the region. The cyclones may differ in their intensity and localization and they may be associated with different SLP patterns over the Northern Hemisphere. An attempt was made to classify the circulation types causing heavy snowfall in the West Siberian Plain. The hierar- 

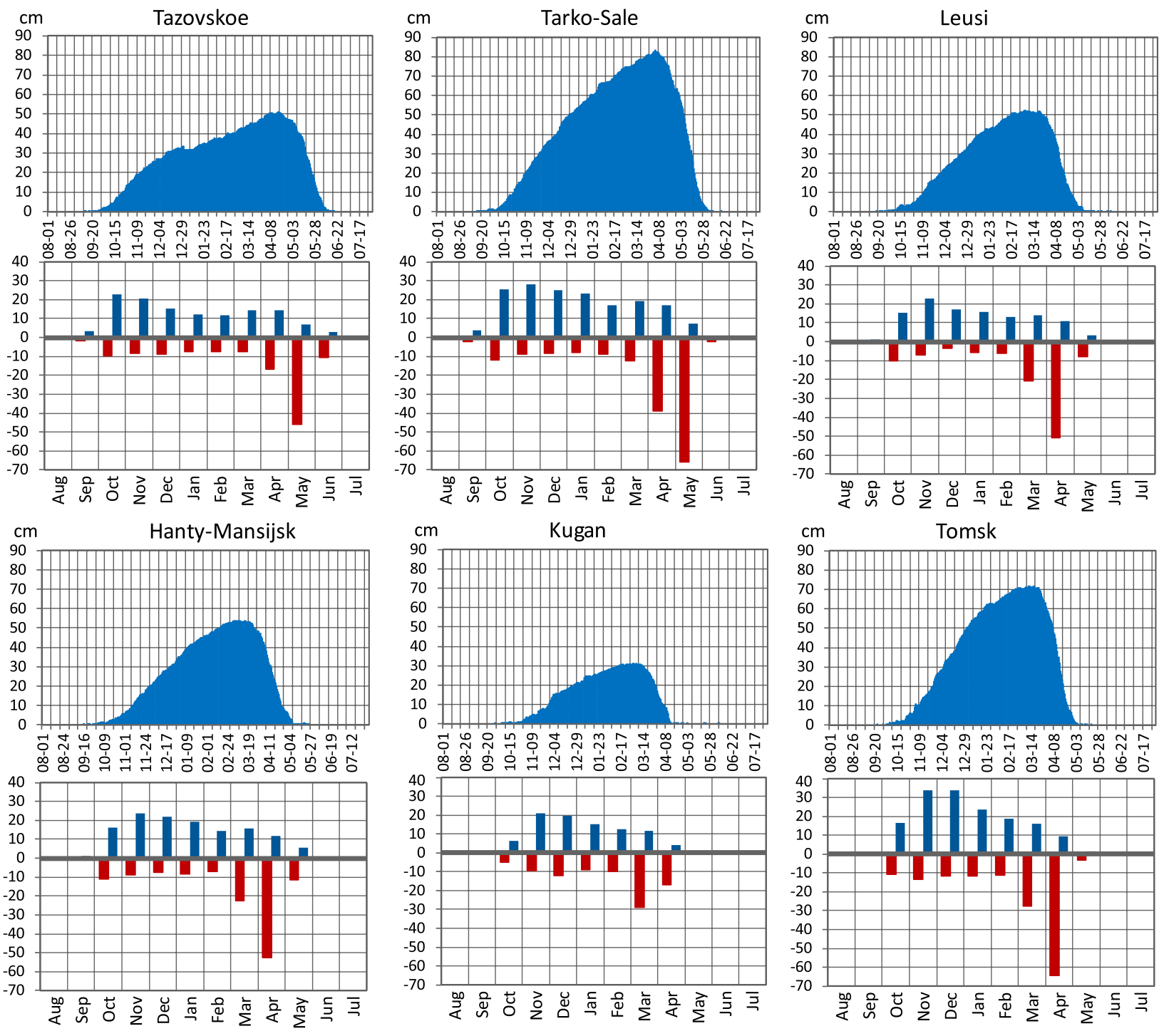

Fig. 2. Upper bar charts - seasonal course of mean daily snow depth (cm); bottom bar charts - mean monthly snow accumulation totals in cm (blue bars) and mean monthly totals of decrease in snow depth (red bars) in cm (averages for period 1978-2008 for selected stations).

chical Ward's minimum variance method was used to cluster the observations. Anomaly maps for SLP of the 4 most relevant groups were constructed (Fig. 5).

The cyclones that bring snowfall in the West Siberian Plain differ in intensity and localization, depending on the area of snowfall. They are sometimes linked by the SLP depressions with the North Atlantic lows, like in Type 1 (Fig. 5). This suggests that they may originate from the North Atlantic and pass to the east along the moderate zone cyclonal track. Low pressure systems over the West Siberian Plain may be also associated with weaker-than-normal Siberian High, like in Type 2. In this case negative anomalies of SLP

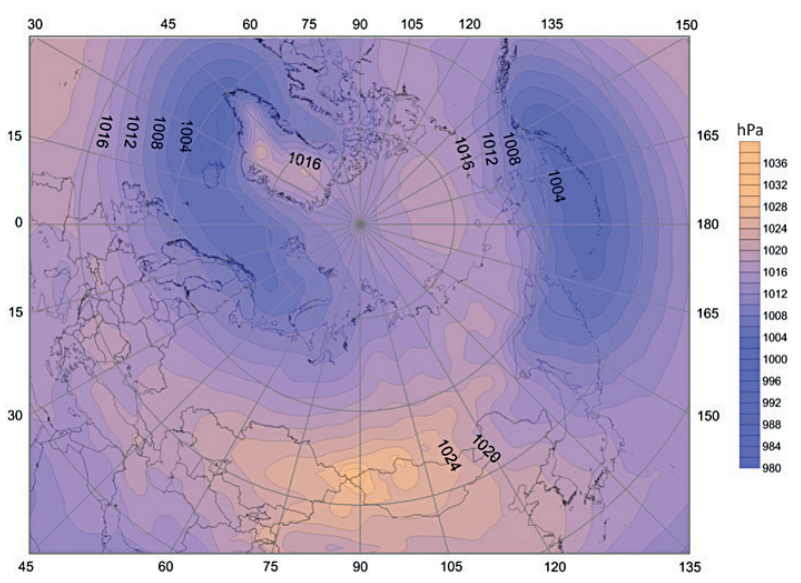

Fig. 3. SLP over the Northern Hemisphere in the cold season (Oct-May). Average for years 1978-2008. 

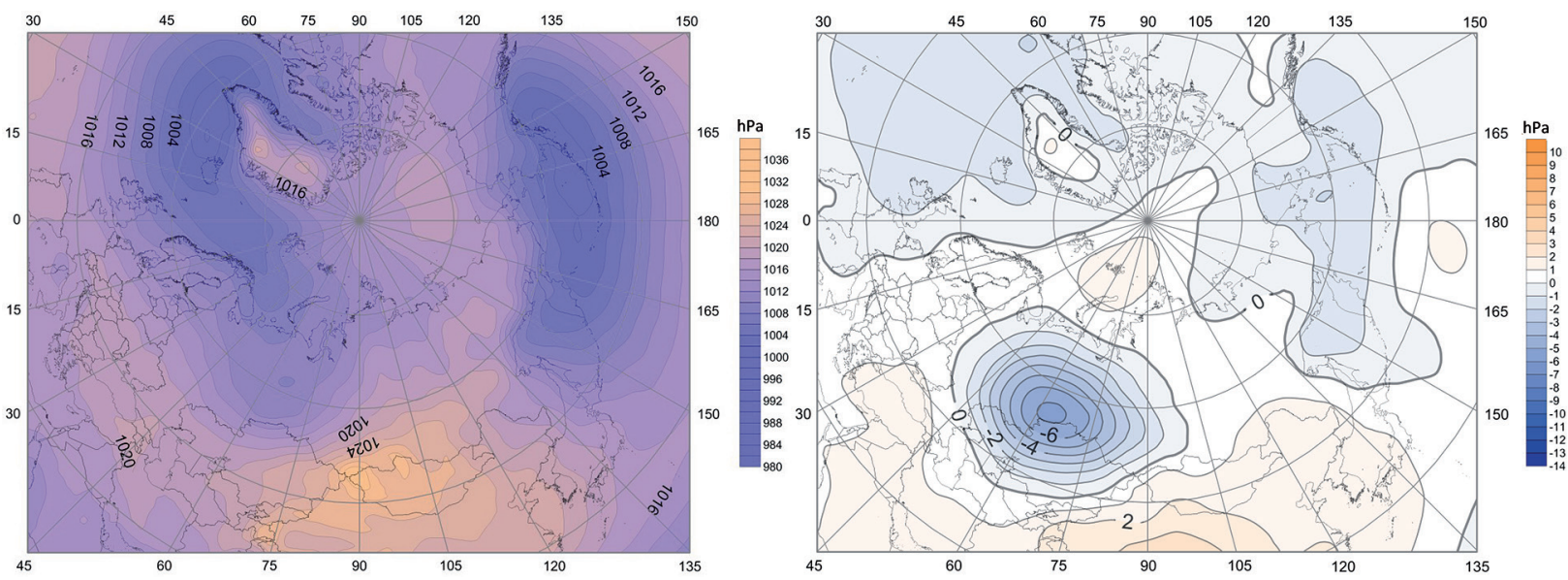

Fig. 4. Mean SLP (left) and anomalies (right) during the days with intensive snowfall, ie., with snow cover increases by at least $5 \mathrm{~cm}$ in at least two stations.

spread over the entire Asia and over the south of Europe, while positive anomalies are observed over the North Atlantic and North Pacific. The cyclones that cause snowfall in the West Siberian Plain, particularly in the north of the region may encompass both the western Siberia and the
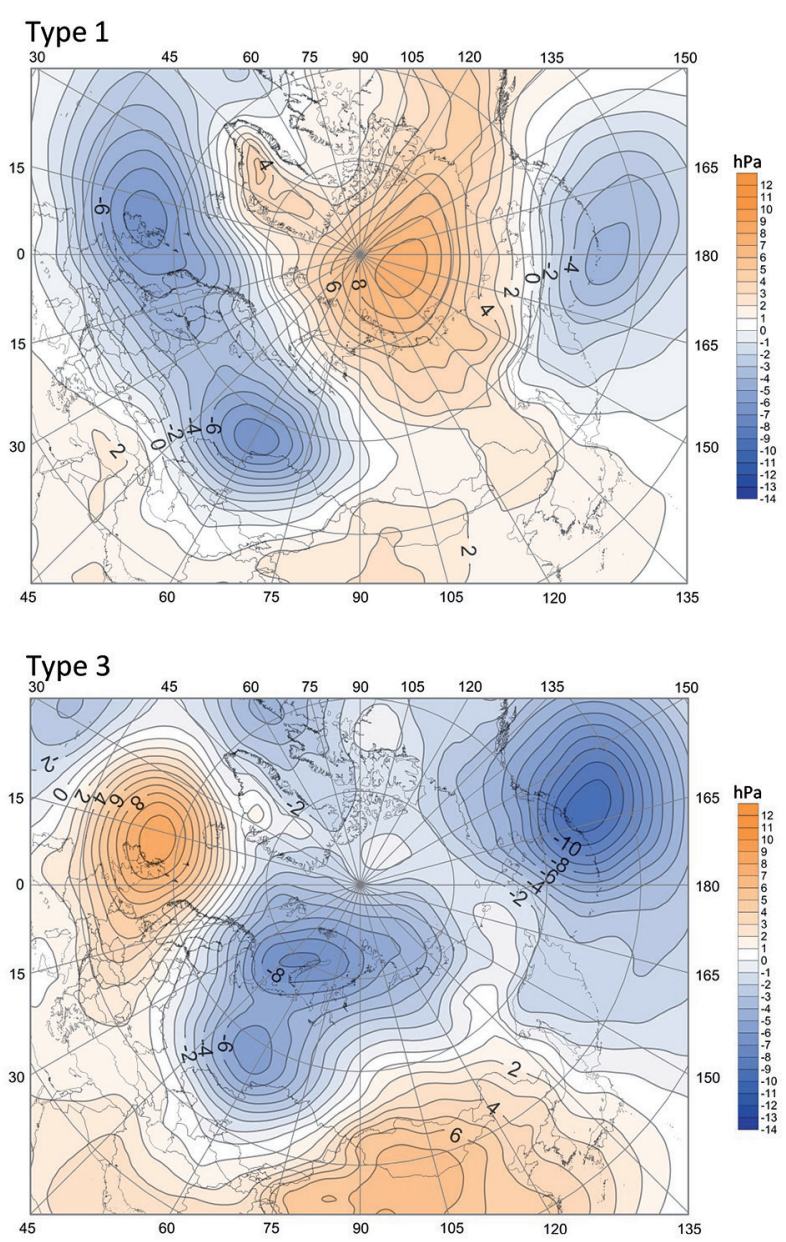

vast part of the Arctic. A low-pressure center locates over the Barents Sea and Novaya Zemlya and a secondary cyclonal center is situated in the south (Type 3 in Fig. 5). Type 3 is associated with the strong Aleutian Low (SLP anomalies exceeding $-12 \mathrm{hPa}$ ). The winter cyclones may also form
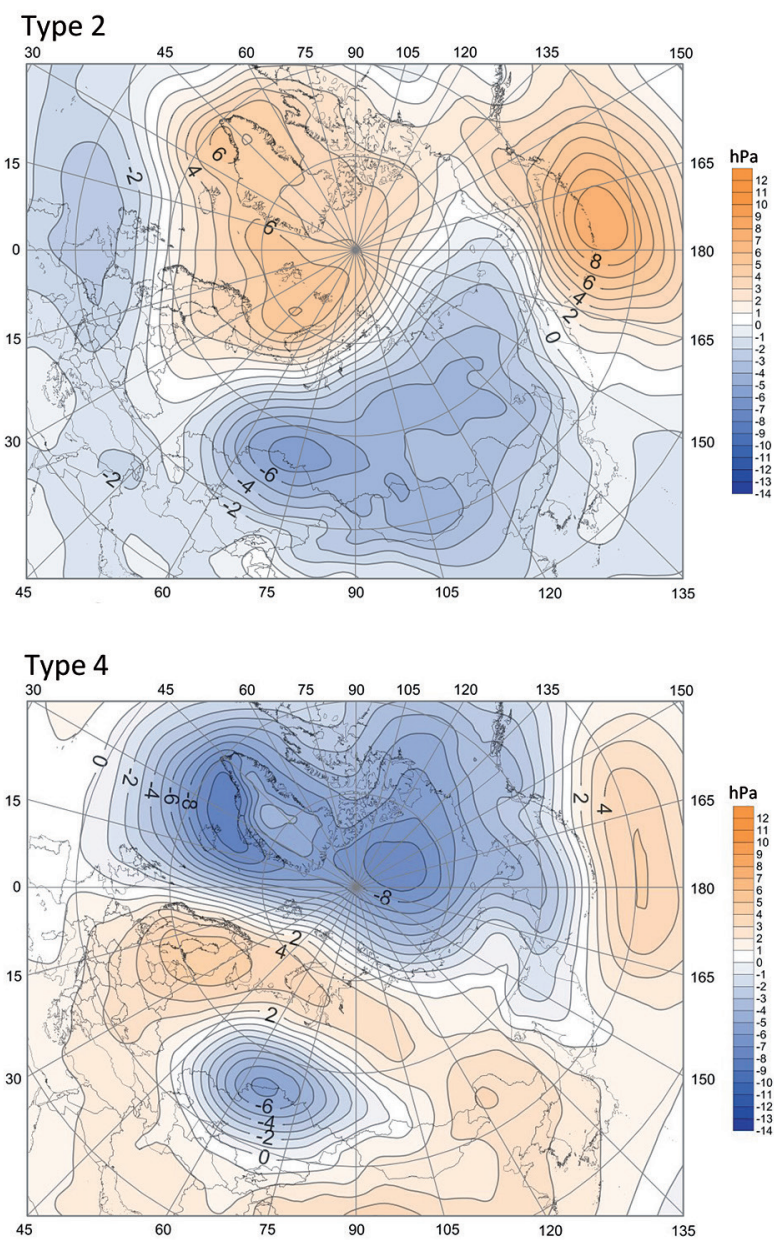

Fig. 5. SLP anomalies for circulation types distinguished for the days with intensive snowfall. 
Table 1. Correlation coefficient between monthly increases in snow cover depth and Siberian High Index.

\begin{tabular}{|l|c|c|c|}
\hline \multicolumn{1}{|c|}{ Station name } & Dec & Jan & Feb \\
\hline Tazovskoe & -0.06 & -0.12 & -0.16 \\
\hline Salehard & -0.05 & -0.09 & -0.29 \\
\hline Tarko-Sale & -0.13 & $-\mathbf{0 . 3 8}$ & $-\mathbf{0 . 3 3}$ \\
\hline Berezovo & -0.09 & -0.08 & -0.30 \\
\hline Njaksimvol & 0.04 & -0.22 & -0.26 \\
\hline Hanty-Mansijsk & -0.30 & -0.44 & -0.37 \\
\hline Leusi & -0.13 & -0.23 & -0.31 \\
\hline Tobolsk & -0.18 & $-\mathbf{0 . 3 2}$ & $-\mathbf{0 . 3 8}$ \\
\hline Tjumen & -0.22 & -0.26 & -0.39 \\
\hline Ekaterinburg & -0.16 & -0.09 & $-\mathbf{0 . 3 4}$ \\
\hline Tara & -0.37 & -0.35 & -0.59 \\
\hline Kurgan & -0.22 & $-\mathbf{0 . 3 0}$ & $-\mathbf{0 . 3 1}$ \\
\hline Omsk & -0.40 & -0.55 & -0.55 \\
\hline Troizk & -0.16 & 0.05 & -0.08 \\
\hline Cerlak & $-\mathbf{0 . 3 2}$ & -0.26 & $-\mathbf{0 . 3 4}$ \\
\hline Sredny Vasjugan & -0.33 & -0.46 & -0.44 \\
\hline Kolpasevo & -0.28 & $-\mathbf{0 . 4 4}$ & $\mathbf{- 0 . 4 3}$ \\
\hline Pudino & -0.49 & -0.53 & -0.30 \\
\hline Tomsk & -0.27 & $\mathbf{- 0 . 5 0}$ & $\mathbf{- 0 . 3 1}$ \\
\hline Barabinsk & -0.50 & -0.48 & -0.25 \\
\hline Vas & & \\
\hline
\end{tabular}

Values statistically signifficant at $p=0.95$ in bold.

locally over the southern part of the analyzed region. In this case snowfalls are observed locally, over the southernmost part of the West Siberian Plain (Type 4 in Fig. 5). Most pressure patterns causing snowfalls characterize with the Siberian High weaker than normal or shifted to the south. This relationship is confirmed by negative values

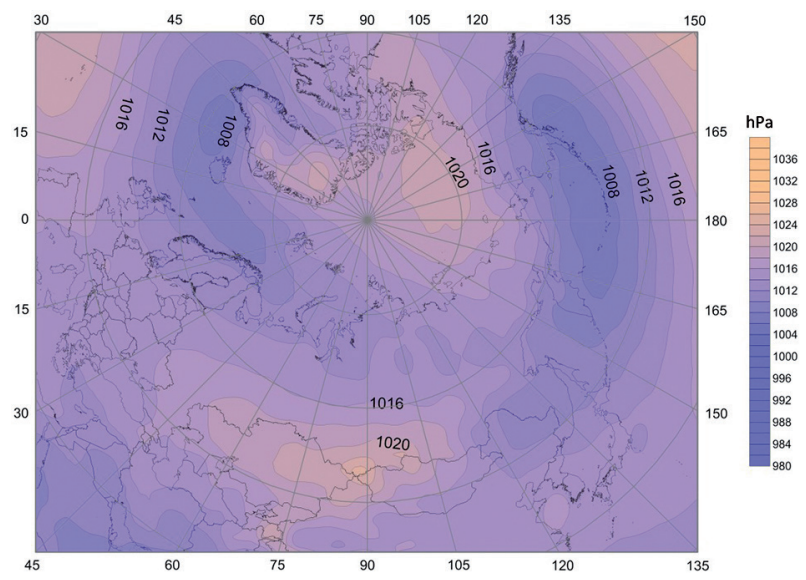

Fig. 6. SLP over the Northern Hemisphere in spring (Mar-May). Average for years 1978-2008.

of correlation coefficients between monthly sums of snow cover increases and the $\mathrm{SH}$ intensity, computed for December, January and February (Table 1). Values are statistically significant only for the southeastern station of the West Siberian Plain. Correlation between monthly sums of snowfalls and the AO index are positive, but low and not statistically significant.

After the long Siberian winter which characterizes with continuous snow accumulation, the short period of snow melting comes in spring. It persists one or two month in the period between March and May. Maximum ablation is observed in May in the north and in April in the south of the analyzed region (Fig. 2, lower bar charts).

In spring the Siberian High, which is a seasonal anticyclone of the thermal origin, weakens remarkably and the mean SLP computed for the period from March to May in the anticyclone center hardly exceeds $1020 \mathrm{hPa}$ (Fig. 6). At the
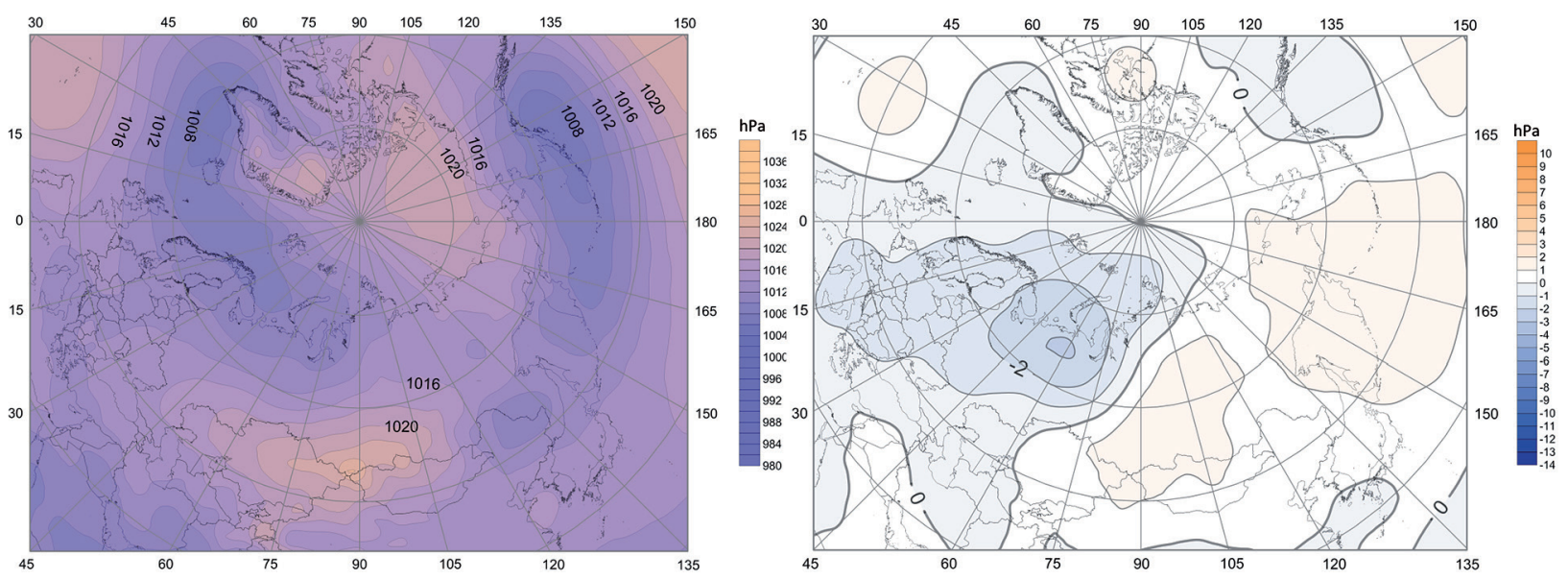

Fig. 7. Mean SLP (left) and anomalies (right) during the days with intensive snowmelt, ie, with snow cover decreases by at least $5 \mathrm{~cm}$ in at least two stations. 

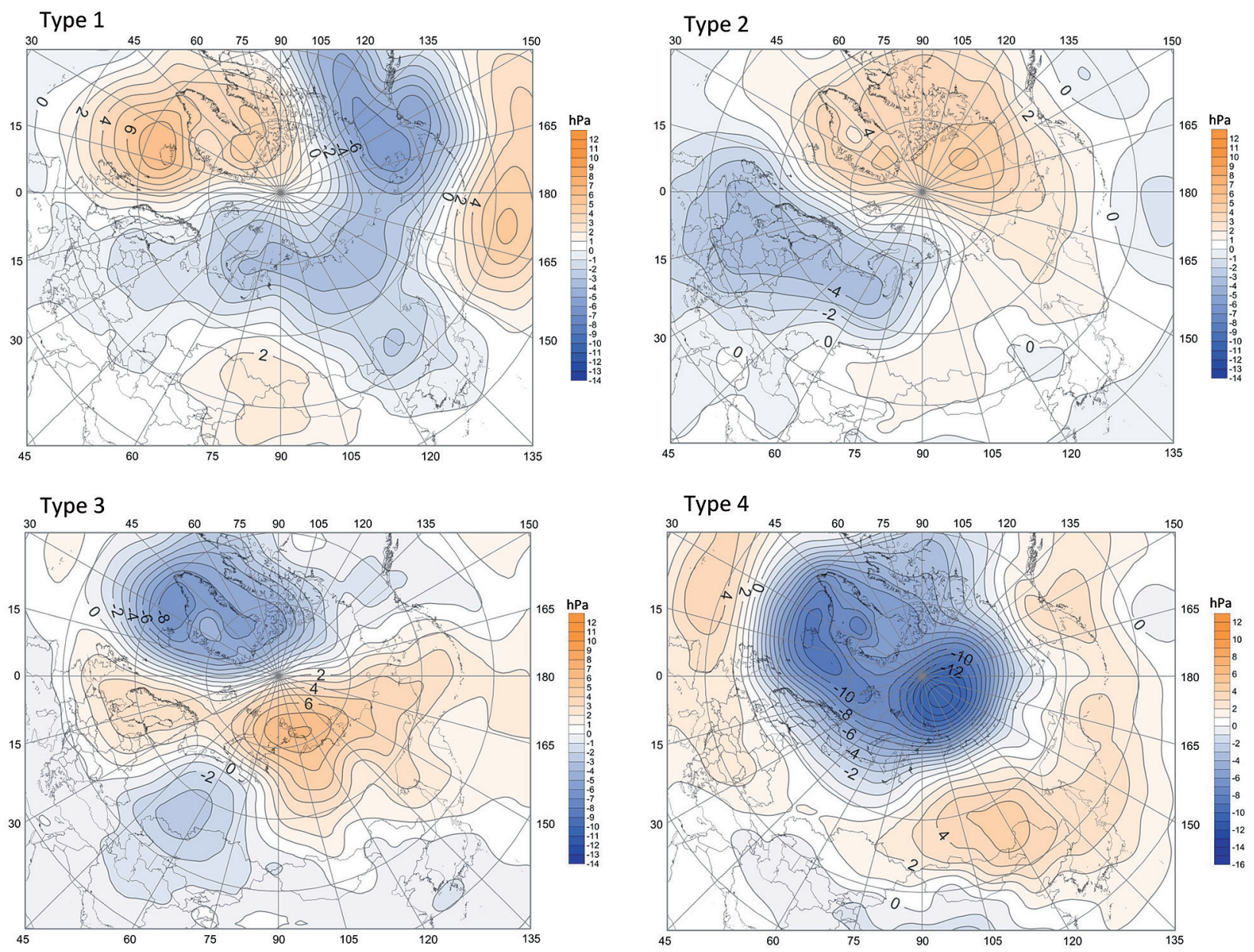

Fig. 8. SLP anomalies for circulation types distinguished for the days with intensive snowmelt.

same time low pressure systems over the North Atlantic (Icelandic Low) and over the North Pacific (Aleutian Low) get weaker, which makes the spring pattern of SLP over the Northern Hemisphere flatter than in winter.

Maps of SLP constructed for the days with intense snow ablation (composites and anomalies) show weak negative anomalies over the analyzed region, with the extreme values exceeding $-4 \mathrm{hPa}$ locally in the north. Such layout of isobars suggest stronger-than normal westerly and southwesterly inflow of air masses to the West Siberian Plain (Fig. 7).

Clustering the SLP patterns, which cause rapid ablation in the West Siberian Plain, allowed distinguishing four different circulation types favorable to snowmelt. Anomaly maps for each of them are in Fig. 8. Each type characterizes with negative anomalies of SLP over entire or part of the western Siberia. The layout of isolines suggests higher-than-normal share of western (Types 1 and 2 in Fig. 8), south-western (Type
4) or southern (Type 3) directions of air inflow. Rapid ablation conditions are often associated with lower than normal pressure in the Arctic, which means increased cyclonal activity in high latitudes (Types 1 and 4 in Fig. 8). In Type 2 in area of lower-than-normal pressure encompasses Europe and in Type 3 increased cyclogenesis is observed over the North Atlantic (Type 3). Much lower SLP anomalies occur during snow ablation in spring than during snow accumulation in winter may suggest smaller influence of air circulation on snow cover reduction in spring and higher impact of insolation.

\section{Discussion and conclusions}

The snow cover season in the West Siberian Plain lasts from approximately eight months in the north to about five months in the south. Previous studies have shown that winter snow accumulation has increased in Eurasia (Ye et al. 
1998, Brown 2000, Ye 2000, Ye 2001a). Moreover, regarding the predicted increase in winter precipitation, greater amounts of snowfall can be expected in high latitudes (Räisänen 2008). The air circulation induced by pressure patterns is a main consideration in investigations on winter weather and climate in middle and high latitudes of Europe and Asia (Hoy et al. 2013). The expected increase in snowfall in middle and high latitude Asia will be controlled by air circulation. The question is which kind of circulation patterns can induce snowfall in particular regions in Eurasia. This study showed that in the West Siberian Plain cyclone activity have a strong impact on the occurrence of abundant snowfall and the occurrence of negative anomalies of SLP usually spread over the area of snowfalls.

The most important center of action in Eurasia during the wintertime is an extensive anticyclone of thermal origin called Siberian High. Changes in its intensity and their contribution to changes in temperature and precipitation over Eurasia have been discussed recently. The ideas have been propagated, that due to the winter warming, the Siberian High, being an anticyclone of thermal origin, was declining in the end of $20^{\text {th }}$ century (Brown 2000, Panagiotopoulos et al. 2005). Recent recovery of the Siberian High intensity which came after a marked weakening trend from the 1970 s to the early 1990s was reported by the latest studies (Jeong 2011). Moreover, the strengthening of the winter Siberian anticyclone was induced by increasing early autumn snowfall, and early formation of snow cover (Saito and Cohen 2003, Allen and Zender 201, Cohen and Jones 2011, Jacobi 2012). The inverse relationship between winter snowfall and winter SH intensity was found in this study. Winter precipitation requires cyclonal activity recognized by negative anomalies of SLP over the West Siberian Plain, which are concurrent with weakened and/or pushed southward continental anticyclone. Similar results were obtained by Rikiishi and Sakakibara (2004), who computed correlation coefficients between the snowfall intensity in the Yenisei valley which is an eastern border of the West Siberian Plain and values of SLP in grid points. The center of negative correlation (low pressure) was located east of the valley and the northwesterly circulation was expected over the area of snowfall. Authors suggested that deep snow along the Yenisei river valley is caused by the frequent migration of synoptic disturbances from the Arctic Ocean. Such conditions appear mainly in October-December and are then suppressed by the freezing of the Arctic Ocean. Congruent conditions of snowfall are recognized in the West Siberian Plain, however, the direction of coming cyclones varies from northern and northwestern to western. Several studies point out increasing frequency and intensity of winter cyclones in Northern Hemisphere high latitudes (Konig et al. 1993, Chen and Zhang 1996, McCabe et al. 2001). This factor may contribute to the increase in snow accumulation in the West Siberian Plains.

While Siberian winter is very long and it characterizes with continuous snow accumulation, the period of snow melting in spring is very short and it lasts one or two months. Timing of snow disappearance is very important for water cycle, as the snowmelt water contributes to the runoff of rivers (Ye et al. 2004) and for the climate system, as it contributes to increasing surface temperature (Iijima et al. 2007). Spring snow melting in Siberia is controlled by large scale warm air advection associated with southwesterly winds (Shinoda et al. 2001, Ueda et al. 2003). Pressure patterns which are associated with rapid snowmelt in the West Siberian Plains indicate stronger-than normal westerly and southwesterly inflow of air masses to the analyzed region. However much lower SLP anomalies occurring during snow ablation in spring than during snow accumulation in winter may suggest smaller influence of air circulation on snow cover reduction in spring and higher impact of insolation, which was proved in other studies (Shinoda et al. 2001, Ueda et al. 2003).

\section{Acknowledgements}

This work was supported by the National Science Centre under grant number 2011/01/B/ ST10/01923.

\section{References}

Allen R.J., Zender C.S., 2011. Forcing of the Arctic Oscillation by Eurasian Snow Cover. Journal of Climate 24: 6528-6539. AMAP, 2012. Arctic Climate Issues 2011 Changes in Arctic Snow, Water, Ice and Permafrost. SWIPA 2011 Overview 
Report Arctic Monitoring and Assessment Programme (AMAP), Oslo xi + 97pp.

Barnston A.G., Livezey R.E., 1987. Classification, seasonality and persistence of low-frequency atmospheric circulation patterns. Monthly Weather Review 115: 1083-1126.

Bednorz E., 2004. Snow cover in eastern Europe in relation to temperature, precipitation and circulation. International Journal of Climatology 24: 591-601.

Bednorz E., Wibig J., 2008. Snow depth in eastern Europe in relation to circulation patterns. Annals of Glaciology 48: 135-149.

Birkeland K.W., Mock C.J., 1996. Atmospheric circulation patterns associated with heavy snowfall events, Bridger Bowl, Montana, USA. Mountains Research and Development 16: 281-286.

Brown R.D., 2000. Northern Hemisphere snow cover variability and change, 1915-97. Journal of Climate 13: 23392355.

Chen S.J., Zhang P.-Z., 1996. Climatology of Deep Cyclones over Asia and the Northwest Pacific. Theoretical and Applied Climatology 54: 139-146.

Clark M.P., Serreze M.C., Robinson A.D., 1999. Atmospheric controls on Eurasian snow extent. International Journal of Climatology 19: 27-40.

Cohen J., Jones J., 2011. A new index for more accurate winter predictions. Geophysical Research Letters 38: L21701.

Cohen J., Entekhabi D., 1999. Eurasian snow cover variability and Northern Hemisphere climate predictability. Geophysical Research Letters 26: 345-348.d

Dayan U., Tubia A., Levy I., 2012. On the importance of synoptic classification methods with respect to environmental phenomena. International Journal of Climatology 32: 681-694.

Dewey K.F., 1977. Daily maximum and minimum temperature forecasts and the influence of snow cover. Monthly Weather Review 105: 1594-1597.

Esteban P., Jones P.D., Martin-Vide J, Mases M, 2005. Atmospheric circulation patterns related to heavy snowfall days in Andorra, Pyrenees. International Journal of Climatology 25: 319-329.

Falarz M., 2007. Snow cover variability in Poland in relation to the macro- and mesoscale atmospheric circulation in the $20^{\text {th }}$ century. International Journal of Climatology 27: 2069-2081.

Foster J.L., 1989. The significance of the date of snow disappearance on the Arctic tundra as a possible indicator of climate change. Arctic, Antarctic and Alpine Research 21: 60-70.

Gong D.-Y., Ho C.-H., 2002. The Siberian High and climate change over middle to high latitude Asia. Theoretical and Applied Climatology 72: 1-9.

Gutzler D.S., Rosen R.D., 1992. Interannual variability of wintertime snow-cover across the Northern Hemisphere. Journal of Climate 5: 1441-1447.

Hoy A, Sepp M, Matschullat J, 2013. Large-scale atmospheric circulation forms and their impact on air temperature in Europe and northern Asia. Theoretical and Applied Climatology 113: 643-658.

Iijima Y., Masuda K., Ohata T., 2007. Snow disappearance in eastern Siberia and its relationship to atmospheric influences. International Journal of Climatology 27: 169-177.

Jacobi H.-W., 2012. Snow: a reliable indicator for global warming in the future? Environmental Research Letters 7: 011004 .
Jeong J.-H., Ou T., Linderholm H.W., Kim B.-M., Kim S.-J., Kug J.-S., Chen D., 2011. Recent recovery of the Siberian High intensity. Journal of Geophysical Research 116: D23102.

Kalkstein L.S., Tan G., Skindlov J.A., 1987. An evaluation of three clustering procedures for use in synoptic climatological classifications. Journal of Climatology and Applied Meteorology 26: 717-730.

Kalnay E., Kanamitsu M., Kistler R., Collins W., Deaven D., Gandin L., Iredell M., Saha S., White G., Woollen J., et al, 1996. The NMC/NCAR 40-Year Reanalysis Project. Bulletin of American Meteorological Society 77: 437-471.

Konig W., Sausen R., Sielman F., 1993. Objective identification of cyclones in GCM simulations. Journal of Climate 6: 2217-2231.

McCabe G.J., Clark M.P., Serreze M., 2001. Trends in Northern Hemisphere surface cyclone frequency and intensity. Journal of Climate 14: 2763-2768.

Meehl G.A., Stocker T.F., Collins W., Friedlingstein P., Gaye A., Gregory J., Kitoh A., Knutti R., Murphy J., Noda A,. et al, 2007. Global climate projections In: Solomon S, et al (eds) Climate Change 2007: the physical science basis. London: Cambridge University Press, pp 747-845.

Morinaga Y., Tian S.-F., Shinoda M., 2003. Winter snow anomaly and atmospheric circulation in Mongolia. International Journal of Climatology 23: 1627-1636.

Panagiotopoulos F., Shahgedanova M., Hannachi A., Stephenson D.B., 2005. Observed Trends and Teleconnections of the Siberian High: A Recently Declining Center of Action. Journal of Climate 18: 1411-1422.

Peings, Y., Brun E., Mauvais V., Douville H., 2013., How stationary is the relationship between Siberian snow and Arctic Oscillation over the 20th century? Geophysical Research Letters 40, 183-188, doi: 10.1029/2012GL054083.

Popova V., 2007. Winter snow depth variability over northern Eurasia in relation to recent atmospheric circulation changes. International Journal of Climatology 27: 1721-1733.

Przybylak R., 2000. Temporal and spatial variation of surface air temperature over the period of instrumental observations in the Arctic. International Journal of Climatology 20: 587-614.

Räisänen J., 2008. Warmer climate: less or more snow? Climate Dynamics 30: 307-319.

Rikiishi K., Sakakibara J., 2004. Seasonal cycle of the snow coverage in the former Soviet Union and its relation with atmospheric circulation Annals of Glaciology 38: 106-114.

Robinson D.A., Kukla G., 1985. Maximum surface albedo of seasonally snow-covered lands in the Northern Hemisphere. Journal of Applied Meteorology and Climatology 24: 402-411.

Robock A., 1980. The seasonal cycle of snow cover, sea ice and surface albedo. Monthly Weather Review 108: 267-285.

Saito K., Cohen J., 2003. The potential role of snow cover in forcing interannual variability of the major Northern Hemisphere mode. Geophysical Research Letters 30: 1302.

Shinoda M., Utsugi H., Morishima W., 2001. Spring snow-disappearance timing and its possible influence on temperature fields over central Eurasia. Journal of Meteorological Society of Japan 79: 37-59.

Tachibana Y., 1995. A statistical study of the snowfall distribution on the japan Sea side of Hokkaido and its relation to synoptic-scale and meso-scale environments. Journal of Meteorological Society of Japan 73: 697-715.

Ueda H., Shinoda M., Kamahori H., 2003. Spring northward retreat of Eurasian snow cover relevant to seasonal and 
interannual variations of atmospheric circulation. International Journal of Climatology 23: 615-629.

Wagner A.J., 1973. The influence of average snow depth on monthly mean temperature anomaly. Monthly Weather Review 101: 624-626

Walsh J.E., Tucek D.R., Peterson M.R., 1982. Seasonal snow cover and short-term climatic fluctuations over the United States. Monthly Weather Review 110: 1474-1485.

Ward J.H., 1963. Hierarchical grouping to optimize an objective function. Journal of American Statistical Association 58: 236-244.

Yabuki H., Park H., Kawamoto H., Suzuki R., Razuvaev V.N., Bulygina O.N., Ohata T., 2011. Baseline Meteorological Data in Siberia (BMDS) Version 50 RIGC, JAMSTEC Yokosuka, Japan, distributed by CrDAP, Digital media.

Yarnal B., 1993. Synoptic Climatology in Environmental Analysis. Belhaven Press: London

Yarnal B., Comrie A.C., Frakes B., Brown D.P., 2001. Developments and prospects in synoptic climatology. International Journal of Climatology 21: 1923-1950
Ye H., 2000. Decadal variability of Russian winter snow accumulation and its associations with Atlantic sea surface temperature anomalies. International Journal of Climatology 20: 1709-1728.

Ye H., 2001a. Quasi-biennial and quasi-decadal variations in snow accumulation over northern Eurasia and their connections to the Atlantic and Pacific Oceans. Journal of Climate 14: 4573-4584.

Ye H., 2001b. Increases in snow season length due to earlier first snow and later last snow dates over north central and northwest Asia during 1937-1994. Geophysical Research Letters 28: 551-554.

Ye H., Ellison M., 2003. Changes in transitional snowfall season length in northern Eurasia. Geophysical Research Letters 30: 1252.

Ye H., Cho H.R., Gustafson PE, 1998. The changes in Russian winter snow accumulation during 1936-83 and its spatial patterns. Journal of Climate 11: 856-863.

Ye H., Yang D., Zhang T., Zhang X., Ladochy S., Ellison M., 2004. The impact of climatic conditions on seasonal river discharges in Siberia. Journal of Hydrometeorology 5: 286-295. 